UDC 331.5

DOI: 10.31651/2076-5843-2019-3-28-36

\title{
DZIURNY Anna
}

Adiunkt n-d,

Wydział Nauk Historycznych i Społecznych,

Uniwersytet Kardynała Stefana Wyszyńskiego w

Warszawie,

Warszawa, Poland

ORCID ID: https://orcid.org/ 0000-0002-9190-8086

wnhis@uksw.edu.pl

\section{WYZNACZNIKI RYNKU PRACY W PROCESIE KSZTALTOWANIA KONKURENCYJNOŚCI KRAJU}

\begin{abstract}
Artykut kwestię analiz i ocen konkurencyjności gospodarki narodowej z punktu widzenia efektywności rynku pracy. Przeprowadzone analizy i oceny przez pryzmat licznego zbioru wskaźników (wspótpracę w zakresie stosunków pracy, elastyczność ustalania wynagrodzeń, praktyki zatrudniania i zwalniania, obciażenia wynagrodzeń $w$ tygodniach placenia pensji, wptyw opodatkowania na zachęty do pracy, placa $i$ wydajność, poleganie na profesjonalnej kadrze zarzadzajacej, zdolność kraju zatrzymania talentów, zdolność kraju do przyciagania talentów oraz kwestię kobiet na rynku pracy w stosunku do mężczyzn) dowiodty dalece zróżnicowanego poziomu konkurencyjności polskiej gospodarki względem krajów sasiedzkich. Uznać należy go za odbiegajacy od zadawalającego. Konkurencyjność polskiej gospodarki, oceniane z punktu widzenia efektywności rynku pracy, uznać należy za dalece niezadowalajaca. Szansy na poprawe konkurencyjności należy upatrywać $w$ realnych dziataniach a nie $w$ deklaracjach polityki społeczno-gospodarczej. Pomocnym w jej urealnieniu moga okazać się środki unijne, których po pozyskaniu powinny być wtaściwe i efektywne spożytkowanie.
\end{abstract}

Stowa kluczowe: konkurencyjność polskiej gospodarki, rynku pracy, produktywność pracy, opodatkowania na zachęty do pracy, elastyczność.

Wprowadzenie. Współcześnie problemy gospodarki rynkowej związane są ściśle z rynkiem pracy. W rzeczywistości gospodarczej każdego kraju stają się one coraz bardziej aktualne. Coraz częściej podkreśla się, iż rynek pracy powinien być wydajny, elastyczny i efektywny. W rzeczywistości wydajność i elastyczność rynku pracy mają kluczowe znaczenie z jednej strony dla zapewnienia pracownikom godnej i opłacalnej pracy, z drugiej zaś strony do znalezienia sposobu, ażeby pracodawcy najbardziej efektywnie wykorzystali zasoby ludzkie w gospodarce, odnosząc tym samym korzyści.

Przegląd literatury. Problemy analizy niektórych aspektów kształtowania się i specyfiki rynku pracy $\mathrm{w}$ Polsce poświęcone są pracy S. Borkowski, P. Broniatovskaya, A. Bukovski, M. Dobia, J. Zavistovsky, Z. Żółkiewski, K. Kartus, G. Koloch, A. Levandovsky, G. Magda, A. Regulsky K. Cirbus. Badania dotyczą przede wszystkim problemów zarządzania zasobami ludzkimi na rynku pracy, płacy minimalnej w Polsce, źródeł i perspektyw wzrostu wydajności, elastyczności rynków towarowych i rynków pracy w Polsce i Europie, definicji płac i dyskryminacji w zatrudnieniu itp. Jednocześnie kwestie systematycznej analizy czynników wpływających na konkurencyjność Polski wśród sąsiednich krajów na rynku pracy pozostają niedoceniane.

Glównym celem identyfikacja czynników determinujących rynek pracy w procesie kształtowania konkurencyjności kraju.

Wyniki i dyskusja. Problematyka efektywności rynku pracy jest uwzględniana w Globalnym Raporcie Konkurencyjności publikowanym przez Światowe Forum Ekonomiczne [14]. Odnoszona jest ona do zbioru wyznaczników i wskaźników charakteryzujących wiele stron rynku pracy. Wartości wskaźników charakteryzujących rynek pracy prezentowane są w skali od 1 do 7 , gdzie 1 oznacza najniższy poziom oceny danego wyznacznika infrastruktury, a wartość 7 oznacza poziom najwyższy oceny danego wyznacznika.

Mając na uwadze rolę i znaczenie konkurencyjności w procesach rozwojowych polskiej gospodarki zasadnym stało się przeprowadzenie analizy i oceny jej konkurencyjności w relacji do 
gospodarek krajów sąsiedzkich w obszarze rynku pracy. W podjętych analizach i ocenach, uwzględniona został grupa państw sąsiedzkich ograniczona do sześciu krajów, to jest: Czech, Litwy, Niemcy, Rosji, Słowacji i Ukrainy. Białoruś została pominięta w podjętych analizach porównawczych ze względu na fakt braku porównywalnych informacji o konkurencyjności.

Analiza i ocena efektywności rynku pracy w Polsce i krajach sąsiedzkich według wskaźnika GCI (tabela1) wskazują, że na najwyższe oceny zasługują Niemcy. Dalsze zbliżone do siebie wskaźniki i miejsca w rankingach zajmują w kolejności Rosja, Litwa, Czechy, Polska, Ukraina. Najgorzej oceniane jest sytuacja na Słowacji [14, s.166-167, 190-191, 250-251, 310-311, 320-321, 336337, 372-373].

Tabela 1

Czynniki ksztaltowania konkurencyjności na rynku pracy i wskaźniki ich opisu / wartość wskaźnika / ranking 144 krajów/

\begin{tabular}{|c|c|c|c|c|c|c|c|}
\hline & CZECHY & LITWA & NIEMCY & POLSKA & ROSJA & SŁOWACJA & UKRAINA \\
\hline $\begin{array}{c}\text { współpraca w } \\
\text { zakresie } \\
\text { stosunków pracy }\end{array}$ & $5,5 / 52$ & $4,1 / 87$ & $5,2 / 19$ & $4,0 / 100$ & $4,1 / 89$ & $4,0 / 105$ & $3,8 / 119$ \\
\hline $\begin{array}{c}\text { elastyczność } \\
\text { ustalania } \\
\text { wynagrodzeń }\end{array}$ & $5,4 / 43$ & $6,0 / 8$ & $3,4 / 136$ & $5,6 / 29$ & $5,6 / 28$ & $4,6 / 102$ & 4,9 / 77 \\
\hline $\begin{array}{c}\text { praktyki } \\
\text { zatrudniania } \\
\text { i zwalniania }\end{array}$ & $3,2 / 121$ & $3,0 / 125$ & $3,4 / 109$ & $3,4 / 112$ & $4,2 / 41$ & $2,9 / 131$ & $3,9 / 64$ \\
\hline $\begin{array}{c}\text { obciążenia } \\
\text { wynagrodzeń, w } \\
\text { tygodniach } \\
\text { płacenia pensji }\end{array}$ & 20,2 / 95 & $24,6 / 112$ & $21,6 / 100$ & $18,8 / 89$ & $17,3 / 83$ & 18,8 / 89 & $13,0 / 57$ \\
\hline $\begin{array}{c}\text { wpływ } \\
\text { opodatkowania na } \\
\text { zachęty do pracy }\end{array}$ & $3,1 / 110$ & $2,9 / 124$ & $3,7 / 67$ & $3,4 / 88$ & $3,0 / 115$ & $2,9 / 119$ & $2,6 / 135$ \\
\hline $\begin{array}{c}\text { płaca } \\
\text { i produktywność }\end{array}$ & 4,6 / 19 & $4,8 / 12$ & $4,3 / 40$ & $4,1 / 53$ & $4,6 / 24$ & $4,4 / 32$ & 4,5 / 31 \\
\hline $\begin{array}{c}\text { poleganie na } \\
\text { profesjonalnej } \\
\text { kadrze } \\
\text { zarządzającej } \\
\end{array}$ & $4,5 / 47$ & $4,5 / 50$ & $5,5 / 19$ & $4,2 / 71$ & $4,0 / 85$ & $4,2 / 74$ & $3,5 / 115$ \\
\hline $\begin{array}{l}\text { zdolność kraju } \\
\text { do zatrzymania } \\
\text { talentów }\end{array}$ & $3,3 / 80$ & $2,7 / 119$ & $5,1 / 10$ & $2,7 / 117$ & 2,9 / 103 & $2,4 / 130$ & $2,3 / 132$ \\
\hline $\begin{array}{l}\text { zdolność kraju } \\
\text { do przyciągania } \\
\text { talentów }\end{array}$ & $3,1 / 9,3$ & $2,3 / 129$ & $4,7 / 18$ & $2,5 / 124$ & $3,1 / 92$ & $2,6 / 117$ & $2,3 / 130$ \\
\hline $\begin{array}{l}\text { kobiety na rynku } \\
\text { pracy w stosunku } \\
\text { do mężczyzn }\end{array}$ & $0,80 / 74$ & $0,95 / 13$ & $0,87 / 45$ & $0,82 / 69$ & $0,87 / 41$ & $0,80 / 73$ & $0,85 / 52$ \\
\hline $\begin{array}{c}\text { efektywność rynku } \\
\text { pracy }\end{array}$ & $4,3 / 62$ & $4,3 / 53$ & $4,6 / 35$ & $4,1 / 79$ & $4,4 / 45$ & $3,9 / 97$ & $4,1 / 80$ \\
\hline
\end{tabular}

Źródło: [14, s.166-167, 190-191, 250-251, 310-311, 320-321, 336-337, 372-373].

Pierwszym ze wskaźników oceny efektywności rynku pracy wpływającym na konkurencyjność gospodarki narodowej jest współpraca w zakresie stosunków pracy, to jest między pracownikiem a pracodawcą (ang. cooperation in labor-employer relations). Jego wartość określona jest w skali od 1 do 7, gdzie 1 oznacza zupełny brak współpracy, a 7 najwyższy poziom współpracy w zakresie stosunków pracy.

W Polsce strony umów korzystają ze swobody w zakresie kształtowania łączących ich stosunków, czyli zawierający umowę mają prawo ułożyć stosunek prawny według własnego uznania, oczywiście, jeśli jego treść i cel nie sprzeciwiają się właściwości stosunku, ustawie i zasadom współżycia społecznego. 
Obecnie pracodawca $\mathrm{w}$ Polsce, może podpisać umowę $\mathrm{z}$ pracownikiem $\mathrm{w}$ dwóch podstawowych formach: umowy o pracę, umowę cywilnoprawną. Na rynku pracy istnieją jeszcze dwie inne, coraz częściej stosowane formy, a mianowicie samozatrudnienie oraz umowa zlecenie z samozatrudnieniem.

Za podstawową formę zatrudnienia uznaje się stosunek pracy. Forma ta jest bardzo korzystna dla pracowników i zarazem najbardziej kosztowna dla pracodawców. Przy zatrudnieniu pracownika $\mathrm{w}$ takiej formie, pracodawca musi pamiętać o całym systemie gwarancji i uprawnień i wielu ograniczeniach. Jej podstawą jest sporządzana na piśmie umowa o pracę gwarantująca odpłatność zatrudnienia, wypłacaniem wynagrodzenia $\mathrm{w}$ określonym czasie $\mathrm{i}$ zapewniająca pracownikowi obowiązkowe ubezpieczenie społeczne. Umowa powinna być sporządzona pisemnie. Występuje ona w formie: umowę o pracę na czas próby, umowa o pracę na czas wykonania określonej pracy, umowę o pracę na czas określony, umowę na czas określony, na zastępstwo i umowa na czas na nieokreślony [13, s.3].

Kolejną formą pracy, jest to umowa cywilnoprawna, często nazywana „alternatywną” formą zatrudnienia. W tym przypadku występują dwie formy: umowa zlecenie (czyli świadczenie usług) oraz umowa o dzieło. Te formy nie zapewniają ochrony wynikające z przepisów prawa pracy [13, s.7]. Spośród nich najbardziej popularną formą jest umowa zlecenia. Przedmiotem tej umowy jest wykonanie określonych czynności przez zleceniobiorcę dla zleceniodawcy, a istotą jej jest oczekiwany rezultat wykonanych czynności który jest tylko prawdopodobny, przy czym ryzyko wykonania umowy ponosi zleceniodawca. Stronami umowy zlecenia mogą być dowolne osoby fizyczne lub osoby prawne. Może być zawierana odpłatnie lub nieodpłatnie, ale nie musi mieć formy pisemnej[13, s.8-10].

Kolejna forma umowy cywilnoprawnej jest umowa o dzieło na której podstawie przyjmujący zamówienie zobowiązuje się do wykonania oznaczonego działa, a zamawiający do zapłaty umówionego wynagrodzenia, nazywamy ją tak zwana umową rezultatu. Dla ważności umowy o dzieło może być ona zawarta pisemnie jak i ustnie. Nie jest ona ograniczona terminem [13, s.10].

W ostatnim okresie czasu bardzo popularną formą jest samozatrudnienie, czyli prowadzenie własnej działalności gospodarczej, ze względu na wysokie koszty pracy. Charakter samozatrudnienia wyróżnia się odmiennym ukształtowaniem stosunku pracownik - pracodawca. $\mathrm{W}$ tej formie mamy do czynienia $\mathrm{z}$ stosunkiem pracy kształtującym się pomiędzy przedsiębiorcami, którzy przynajmniej teoretycznie są równorzędnymi partnerami. Samozatrudnienie cechuje się często swobodą w organizacji własnej pracy [13, s.11-12].

Oceny współpracy w zakresie stosunków pracy, między pracownikiem a pracodawcami według wskaźnika GCI (tabela1) wskazują, że na najwyższym poziomie jest ona w Niemczech. Dalsze miejsca zajmują Litwa i Rosja. Najgorzej oceniane jest ona w Polsce, Słowacji i na Ukrainie.

Elastyczność ustalenia wynagrodzeń (ang. flexbility of wage determination), to kolejny wskaźnik oceny efektywności rynku pracy. Jego wartość określona jest w skali od 1 do 7 , gdzie 1 oznacza zupełny brak, a 7 najwyższy poziom elastyczności ustalenia wynagrodzeń.

W Polsce pojęcie „wynagrodzenie za pracę” nie jest jednoznacznie zdefiniowane w kodeksie pracy. Określa się je jako świadczenie, jakie pracodawca zobowiązany jest wypłacić pracownikowi okresowo w zamian za wykonaną przez niego pracę, odpowiednio do rodzaju tej pracy, ilości oraz jakości. Jej wysokość, zależy w teorii od ustaleń, jakie strony podejmują podpisując umowę o pracę. Pracodawca przy zatrudnieniu może brać pod uwagę kwalifikacje pracownika, jego doświadczenie, wiedzę i zaproponować odpowiednią wysokość wynagrodzenia. Jak również może brać pod uwagę oczekiwania drugiej strony nawiązanego stosunku prawnego - stosunku pracy [9, s.4].

Płaca minimalna jest to podstawowa stawka wynagrodzenia, jaką pracownik, może dostać w ramach umowy o pracę. Spośród 28 państw członkowskich Unii Europejskiej 21 krajów posiada regulacje dotyczące wynagrodzenia minimalnego obowiązujące na poziomie krajowym. Wysokość wynagrodzenia minimalnego ustala jest ustawowo lub $\mathrm{w}$ drodze negocjacji $\mathrm{z}$ partnerami społecznymi. Państwami w UE, które nie mają ustalonej stawki wynagrodzenia minimalnego (płacy 
minimalnej), tylko regulacje na poziomie krajowym są to: Dania, Austria, Finlandia, Szwecja, Niemcy, Cypr i Włoch.

Pod względem nominalnym wartość płacy minimalnej, wyrażonej w euro, Polska w 2014 roku, zajmowała 13 miejsce wśród 21 krajów UE. Najwyższa stawka wynagrodzenia minimalnego obowiązuje w Luksemburgu - 1921 euro, prawie pięć razy więcej niż w Polsce, w której stawka ta wynosi 387 euro. Natomiast najniższa stawka wynagrodzenia minimalnego odnotowana jest w Bułgarii i wynosi 174 euro [15, s. 5-7].

W realiach konkretnego rynku pracy wynagrodzenie ma zawsze prawny aspekt jego kształtowania. Po pierwsze to pracodawca jest w praktyce stroną, która ustala wynagrodzenie, jego wysokość i poszczególne składniki. Pracodawcy niezobowiązani przepisami szczególnymi posiadają dużą swobodę, tworząc system wynagrodzeń. Mogą oni swobodnie wybierać spośród różnych, możliwych form wynagrodzenia swoich pracowników oraz swobodnie ustalać, jakie składniki przysługiwać im będą z tytułu wykonywanej pracy. Pracodawca może wprowadzić różne formy wynagrodzenia dla różnych grup zawodowych, a także dla poszczególnych pracowników. Po drugie pracownik podpisując umowę o pracę, w większości przypadków przyjmuje „odgórne” zaproponowane mu warunki. Faktyczny udział pracowników w kształtowaniu wysokości swojego wynagrodzenia, jest niewielki. Jednym z podstawowych zasad prawa pracy jest równe traktowanie, którego wyrazem jest równe wynagrodzenie za jednakową pracę lub za pracę o jednakowej wartości $[9$, s.6].

Ważną kwestią kształtowania sytuacji na rynku pracy jest stawka wynagrodzenia minimalnego. Konstytucyjnie w Polsce wysokość płacy minimalnej jest regulowany ustawowo. Zgodnie z nimi gwarantowany jest coroczny wzrost płacy minimalnej, nie niższy niż prognozowany na dany rok wzrost poziomu cen. Wysokość wynagrodzenia minimalnego na kolejny rok kalendarzowy ustalana jest co roku w drodze negocjacji na forum Trójstronnej Komisji do spraw Społeczno - Gospodarczych.

Trzecim ze wskaźników oceny efektywności rynku pracy wpływającym na konkurencyjność gospodarki narodowej są praktyki zatrudniania i zwalniania (ang. hiring and firing practices). Jego wartość określona jest w skali od 1 do 7 , gdzie 1 oznacza najniższy poziom, a 7 najwyższy poziom oceny praktyk zatrudniania i zwalniania.

Wskaźnik praktyki zatrudniania i zwalniania dokonuje oceny dwóch stron zarządzania zasobami pracy, z jednej strony zatrudnianiem z drugiej strony zwalnianiem pracownika. Zabiegi te podlegają i są regulowane określonymi procedurami wynikającymi zarówno z tradycji jak i obowiązujących w danym kraju norm prawnych. Są one również istotnym elementem polityki kadrowej każdej organizacji, tak w sferze produkcyjnej jak i budżetowej. Sprowadza się ona do działań organizacyjno-kadrowych mających na celu obsadzenie stanowisk pracy. Koncentruje się ona na rozwiązywaniu zagadnień: doboru pracowników, ich szkoleniem i doskonaleniem zawodowym, motywowaniem do wykonywania zadań, ocenami pracowników, systemami awansowania, a także zwalnianiem pracowników.

Zatrudnieniu może podlegać każda osoba (również ucząca się), która wyrazi chęć pracy, ma odpowiednie wykształcenie, a także spełnia wszystkie warunki prawne. Zatrudnienia, tak jak pracy, nie można posiadać na własność. Może nam je ktoś dać, ale również może nam je odebrać. Zatrudnianie odbywa się na podstawie umowy o pracę $z$ pracodawcą na zasadzie najmu, mianowania lub współużytkowania środków produkcji. Zwalnianie zaś może dokonywać się z inicjatywy zatrudnionego jak i pracodawcy [7, s.196].

Wartość wskaźnika GCI określającego praktyki zatrudniania i zwalniania (tabela 1) lokuje na pierwszym miejscu spośród krajów bezpośredniego otoczenia Polski lokuje Rosję i Ukrainę. Na dalekich miejscach według rankingu konkurencyjności lokują się w kolejności Niemcy, Polska, Czechy, Litwa i Słowacja.

Kolejnym ze wskaźników oceny efektywności rynku pracy wpływającym na konkurencyjność gospodarki narodowej są obciążenia wynagrodzeń, w tygodniach płacenia pensji (ang. redundancy costs, weeks of salary). Przy czym przez pensję rozumie się wynagrodzenie, jakie pracodawca zobowiązany jest wypłacić pracownikowi okresowo w zamian za wykonaną przez niego pracę, 
odpowiednio do rodzaju tej pracy, ilości oraz jakości. Jej wysokość, zależy od ustaleń, jakie strony podejmują podpisując umowę o pracę.

Wynagrodzenie w praktyce podlega ustawowym obciążeniom, które mają charakter podatkowy i nie podatkowy. Obciążenia podatkowe to podatek należny od osób fizycznych opłacany na zasadach ogólnych, ryczałt od przychodów ewidencjonowanych oraz karta podatkowa. Z kolei obciążenia nie podatkowe to te które mają charakter danin. W Polsce są nimi składki na: Fundusz Ubezpieczeń Społecznych (ubezpieczenie emerytalne, ubezpieczenie rentowe), Fundusz Ubezpieczeń Zdrowotnych, Fundusz Pracy, Fundusz Gwarantowanych Świadczeń Pracowniczych, a także Państwowy Fundusz Rehabilitacji Osób Niepełnosprawnych.

Wartość wskaźnika GCI określającego obciążenia wynagrodzeń (tabela 1), w tygodniach płacenia pensji lokuje czele rankingu państw sąsiedzkich Polski Litwę. Na dalszych miejscach plasują się Rosja, Polska, Słowacja, Czechy i Niemcy. Najgorzej pod tym względem oceniana jest Litwa.

Piątym ze wskaźników oceny efektywności rynku pracy wpływającym na konkurencyjność gospodarki narodowej jest wpływ opodatkowania na zachęty do pracy (ang. effect of taxation on incentives to work). Jego wartość określona jest w skali od 1 do 7 , gdzie 1 oznacza najniższy poziom, a 7 najwyższy poziom wpływu opodatkowania na zachęty do pracy.

Opodatkowanie, rozumiane jest jako całość obciążeń podatkowych oraz tak zwanych obciążeń parapodatkowych nakładanych na pracę, prowadzi do zróżnicowania całkowitego kosztu pracy i wynagrodzenia netto otrzymywanego przez pracownika. Tym samym można się spotkać z opiniami, iż zaburza to związek między kosztem pracy, wynagrodzeniem a krańcową produktywnością pracy i zmniejszeniem bodźca do podejmowania zatrudnienia i zwiększenia indywidualnej podaży pracy [10, s.2].

Licząc sumarycznie wysokość pozapłacowych kosztów pracy determinowana jest zarówno przez podatki i parapodatki nakładane bezpośrednio na pracę, jak i inne podatki wpływające na siłę nabywczą dochodu z pracy (opodatkowanie konsumpcji poprzez VAT czy akcyzę). Opodatkowanie pracy stanowi około 43\% dochodów sektora publicznego [8, s.13-14].

Ze względu na wpływ opodatkowania na zachęty do pracy wartość wskaźnik GCI (tabela 1) lokuje wśród państw sąsiedzkich na czołowym miejscu Niemcy, a następnie Polskę. Na dalszych miejscach w rankingu konkurencyjności lokują się w kolejności Czechy, Rosja, Słowacja, Litwa oraz Ukraina.

Kolejnym ze wskaźników oceny efektywności rynku pracy wpływającym na konkurencyjność gospodarki narodowej jest płaca i produktywność (ang. pay and productivity). Jego wartość określona jest w skali od 1 do 7 , gdzie 1 oznacza najniższy poziom, a 7 najwyższy poziom wpływu produktywności (wydajności) na poziom płacy.

Produktywność pracy - rozumiana jako wydajność pracy - jest tą zmienną od której zależy wzrost dobrobytu, wzrost ekonomiczny, siła i stabilność pieniądza, a także dopuszczalny rozmiar sektora publicznego. W nowoczesnym państwie muszą istnieć instytucje upoważnione do kontroli produktywności pracy zarówno retrospektywnie, jak i prospektywnie [5, s.8].

Istotną kwestią w określaniu produktywności pracy są miary produktywności. Mogą być one przedstawiane dwojako, po pierwsze liczone ze względu na wagę dla porównań międzynarodowych, po drugie, jako produktywność dla danego kraju liczoną łącznie dla całej gospodarki [3, s.6].

Najprostszym sposobem ilustrowania produktywności jest porównywanie produktu na jednostkę nakładu pracy. Za produkt przyjmuje się PKB, względnie wartość dodaną, za jednostkę nakładu pracy - jednego zatrudnionego lub jedną godzinę nakładu pracy. Przy całej swej prostocie metoda ta umożliwia mierzenie produktywności na niskim poziomie agregacji, nawet na poziomie przedsiębiorstw (gdzie jako produkt stosuje się dane dotyczące np. produkcji sprzedanej) oraz dokonywanie czytelnych porównań między krajami, sekcjami lub przedsiębiorstwami.

Siódmym wskaźnikiem oceny efektywności rynku pracy wpływającym na konkurencyjność gospodarki narodowej jest poleganie na profesjonalnej kadrze zarządzającej (ang. reliance on professional management). Jego wartość określona jest w skali od 1 do 7 , gdzie 1 oznacza najniższy poziom, a 7 najwyższy poziom polegania na profesjonalnej kadrze zarządzającej. 
Zarządzenie zasobami ludzkimi ukształtowało się pod wpływem szerokiego zbioru uwarunkowań środowiskowych [1, s.208]. Jednym z nich jest profesjonalizm zarządzania nimi. To zaś wymaga odwołania się i wykorzystania dorobku wielu nauk w tym przede wszystkim ekonomicznych, socjologicznych, psychologicznych, fizjologicznych oraz organizacji i zarząania.

Profesjonalne zarządzanie każdą organizacją wymaga wzięcia pod uwagę, iż współczesny rynek pracy i gospodarka oparta na wiedzy stawiają zarządzającym jak i zarządzanym duże wymagania. Szanse na zatrudnienie na danym stanowisku pracy i odniesienie na nim sukcesów wobec wyzwań przed którymi muszą stanąć ludzie zatrudniani w organizacjach na różnych stanowiskach wymuszają od nich posiadanie coraz to innych umiejętności, szerszej wiedzy $\mathrm{i}$ kompetencji. W przedsiębiorstwie prowadzącym działających na globalnym rynku szczególnie pożądane są kompetencje charakterystyczne dla liderów o najwyższych kwalifikacjach, zarówno w zakresie profesji, jak i w odniesieniu do zdolności menedżerskich, a więc najwyższe z możliwych. Oznacza to także konieczność podziału pracowników na cztery kategorie: pracowników wspomagania (funkcji pomocniczych); profesjonalistów i ekspertów (specjaliści najlepsi wśród profesjonalistów); menedżerów o najwyższych kwalifikacjach z zakresu zarządzania; oraz liderów o najwyższych kwalifikacjach - zarówno zawodowych, jak i wynikających $\mathrm{z}$ posiadania kompetencji[6, s.84-90].

Kolejną kwestią jest powstanie na rynku pracy tzw. europejskiego podejścia do zarządzania zasobami. W tym podejściu kapitał ludzki uznawany jest za główny element decydujący o sukcesie strategii organizacji. Zarządzanie zasobami ludzkimi niesie obietnicę, że kierowanie ludźmi i traktowanie ich jako zasobu strategicznego pomoże firmie uzyskać przewagę konkurencyjną i doskonałe wyniki. Zarządzanie zasobami ludzkimi polega zatem na możliwie najbardziej efektywnym wykorzystaniu ludzi w tworzeniu strategii i wdrażaniu jej w życie. Natomiast w psychologii biznesu, specjaliści podkreślają istotę takich elementów, które wpływają na profesjonalizacje zarządzania, jak: pozyskiwanie pracowników, ich motywowanie, rozwój oraz ocenianie [6, s.92-97].

Istotnym wskaźnikiem oceny efektywności rynku pracy wpływającym na konkurencyjność gospodarki narodowej jest zdolność kraju do zatrzymania talentów (ang. country capacity to retain talent). Jego wartość określona jest w skali od 1 do 7 , gdzie 1 oznacza zupełny brak zdolności, a 7 najwyższą zdolność do zatrzymywania w kraju ludzi zdolnych.

Współcześnie uważa się, że kapitał ludzki, jest najważniejszym zasobem gospodarki narodowej. Powszechnym przekonaniem jest to, że najważniejszym bogactwem każdego kraju są nie tyle surowce naturalne i rezerwy walutowe, tylko jego obywatele i ich wiedz, umiejętności i kompetencje. Kapitał ludzki, jest więc postrzegany jako bardzo ważny czynnik rozwoju gospodarczego danego kraju, szczególnie biorąc pod uwagę osoby z wyższym wykształceniem i utalentowane. Obowiązkiem państwa powinno być zapewnienie nie tylko pracy, ale również warunków do dalszego rozwoju. W wielu krajach, szczególnie Europy środkowej i wschodniej państwo nie wywiązuje się $\mathrm{z}$ niego. Ludzie szczególnie uzdolnieni dostają znacznie lepsze propozycje z innych krajów, które są w stanie zapewnić lepsze warunki pracy i życia.

Przedstawiona sytuacja w odniesieniu do Polski, według wielu ekonomistów jest spowodowana „uciekaniem” talentów za granicę. May do czynienia z migracją ludzi młodych - w tym dużej ilości osób z wyższym wykształceniem. Natomiast polski biznes ocenia, że rynek pracy w Polsce w segmencie ludzi zdolnych jest niszczony przez wysokie podatki i nadmierne regulacje.

Dziewiątym wskaźnikiem oceny efektywności rynku pracy wpływającym na konkurencyjność gospodarki narodowej jest zdolność kraju do przyciągania talentów (ang. country capacity to attract talent). Wiąże się on ściśle $\mathrm{z}$ poprzednim wskaźnikiem, reprezentując drugą stronę zjawiska zagospodarowania ludzi zdolnych. Jego wartość określona jest w skali od 1 do 7 , gdzie 1 oznacza zupełny brak zdolności, a 7 najwyższa zdolność do przyciągania ludzi zdolnych.

Zaistniałego stanu rzeczy upatruje się w niewystarczającym wykorzystaniu położenia geopolitycznego, w szczególności atrakcyjności naszego kraju dla wschodnich sąsiadów, jak również niewystarczająco dobrych warunkach pracy i rozwoju. Tym samym powoduje to w sumie niską zdolność do przyciąganiu talentów (ludzi zdolnych i przedsiębiorczych) do naszego kraju. 
Tym zjawiskom nie towarzyszy również niski wskaźnik umiędzynarodowienia wśród krajów OECD.

Ostatnim - dziesiątym - wskaźnikiem oceny efektywności rynku pracy wpływającym na konkurencyjność gospodarki narodowej są kobiety na rynku pracy w stosunku do mężczyzn (ang. women in labor force, ratio to men). Pokazuje on relację liczby kobiet na rynku pracy do ogółu mężczyzn na rynku pracy.

Jedną $\mathrm{z}$ kluczowych cech $\mathrm{w}$ analizie rynku pracy jest płeć. Jest ona istotną kwestią $\mathrm{W}$ odniesieniu do indywidualnych możliwości i decyzji pracowników. Kobiety często pracują w innych zawodach i branżach niż mężczyźni, dostają też inne wynagrodzenie oraz inne warunki pracy. Zróżnicowanie to jest uwarunkowane wieloma czynnikami, między innymi wykształceniem, zaangażowaniem $\mathrm{w}$ życie rodzinne czy też oczekiwaniami życiowymi.

Zjawisko uczestnictwa kobiet na rynku pracy ma uwarunkowania historycznie. Do końca XIX wieku prawo kobiet do pracy zawodowej nie było czymś oczywistym, np. Kodeks Napoleona z 1804 roku pozwalał kobiecie przystąpić do pracy wyłącznie za zgodą męża. Uczestnictwo kobiet uległo zwiększeniu w czasie I wojny światowej, kiedy to kobiety zastąpiły mężczyzn walczących na froncie. Jednakże już w czasie wielkiego kryzysu ponownie wprowadzono ograniczenia $\mathrm{w}$ zatrudnienia kobiet. Dopiero po II wojnie światowej, nastąpił trwały wzrost aktywności zawodowej kobiet. Zjawisko to miało jednak charakter stopniowy [11, s.1].

Obecnie w Polsce ludność w wieku produkcyjnym stanowią kobiety i mężczyźni w wieku 18-67. Osoby do 17 roku życia są zaliczane do grupy w wieku przedprodukcyjnym, zaś kobiety $\mathrm{i}$ mężczyźni w wieku do 67 lat i więcej zaliczani są do grupy w wieku produkcyjnym. Struktury pracujących kobiet i mężczyzn ogółem według wykształcenia są wyraźnie odmienne. Pracujące kobiety najczęściej posiadają wykształcenie wyższe (ok. $40 \%$ pracujących), a następnie średnie (ponad $30 \%$ ). Wśród pracujących mężczyzn dominują posiadający wykształcenie średnie ( ok. $33 \%$ ) i zasadnicze zawodowe (ok. $32 \%$ ) [12, s.1].

Wyższy odsetek kobiet, w stosunku do mężczyzn, pracuje w sektorze publicznym, a niższy w prywatnym. Różnice można również zauważyć, strukturze zatrudnienia. Wśród kobiet jest odsetek pracujących najemnie i pomagających członków rodzin, a niższy - pracujących na własny rachunek i pracodawców. Kobiety najczęściej wykonują prace w zawodach należących do grup: pracownicy biurowi, pracownicy usług osobistych i sprzedawcy oraz specjaliści. Natomiast najmniej kobiet pracowało $\mathrm{w}$ grupach zawodowych: robotnicy przemysłowi i rzemieślnicy oraz operatorzy maszyn i urządzeń.

Kobiety najczęściej zagrożone są bezrobociem długotrwałym. Stopa bezrobocia kobiet jest wyższa niż stopa bezrobocia mężczyzn. Trudniej znaleźć prace kobietą powracającym na rynek pracy po dłuższej przerwie oraz poszukujących pierwszej pracy. Zróżnicowanie stopy bezrobocia w poszczególnych grupach wiekowych przybiera taką samą charakterystykę wśród kobiet i mężczyzn, najwyższa stopa bezrobocia dotyczy osób najmłodszych, później mocna spada, by ustabilizować się na zbliżonym poziomie dla osób powyżej 30 roku życia.

Kolejną bardzo ważna kwestią jest wynagrodzenie. Przeciętnie wynagrodzenie kobiet jest niższe niż wynagrodzenie mężczyzn. W większości sekcji gospodarki narodowej wynagrodzenia kobiet są niższe niż wynagrodzenia mężczyzn. Największą różnicę można zaobserwować w działalności finansowej i ubezpieczeniowej, gdzie przeciętne wynagrodzenie kobiet stanowi niespełna $63 \%$ przeciętnego wynagrodzenia mężczyzn. W sekcjach - dostawa wody oraz administracja i działalność wspierająca - wynagrodzenia są zbliżone. Natomiast przeciętne wynagrodzenie kobiet niż mężczyzn odnotowano jedynie w sekcjach: budownictwo oraz transport $\mathrm{i}$ gospodarka maszynowa. Oczywiście należy zaznaczyć, są to sekcje $\mathrm{z}$ niskim udziałem zatrudnionych kobiet.

Wartość wskaźnika GCI określającego wpływ kobiet na rynku pracy i ich udziału w stosunku do mężczyzn na efektywność rynku pracy (tabela 1) lokuje na pierwszym miejscu Litwę. Dalsze miejsce w rankingach zajmują Rosja, Niemcy i Ukraina. Na dalszej pozycjach lokują się Polska, Słowacja i Czechy.

Podsumowanie. Efektywność rynku pracy jest istotnym obszarem ocen stanu i konkurencyjności gospodarki każdego kraju. Pozostaje ona w obszarze zainteresowań zarówno teorii 
ekonomicznej jak i praktyki życia gospodarczego. Musi być postrzegana przez pryzmat licznego zbioru zjawisk i procesów które powinny być identyfikowane, analizowane i oceniane. Za trafne należy uznać podejście prezentowane w rankingach konkurencyjności, które pozwala ocenić nie tylko na charakterystykę rynku pracy $\mathrm{w}$ danym kraju, ale również na weryfikację stanu koniunktury gospodarczej w danym kraju oraz porównanie jej z innymi krajami.

Charakterystyka efektywności rynku pracy, czego dowiodły rozważania, jest problemem bardzo złożonym. Ważnymi i znaczącymi w ich zbiorze są czynniki kształtujące współpracę w zakresie stosunków pracy, elastyczność ustalania wynagrodzeń, praktyki zatrudniania i zwalniania, obciążenia wynagrodzeń w tygodniach płacenia pensji, wpływ opodatkowania na zachęty do pracy, płaca i wydajność, poleganie na profesjonalnej kadrze zarządzającej, zdolność kraju zatrzymania talentów, zdolność kraju do przyciągania talentów oraz kwestię kobiet na rynku pracy w stosunku do mężczyzn. Ich rozpoznanie i ocenę umożliwiają wskaźniki konkurencyjności GCI charakteryzujące rynek pracy.

Konkurencyjność polskiej gospodarki, oceniane z punktu widzenia efektywności rynku pracy, uznać należy za dalece niezadowalającą. Szansy na poprawę konkurencyjności należy upatrywać $w$ realnych działaniach a nie w deklaracjach polityki społeczno-gospodarczej. Pomocnym w jej urealnieniu mogą okazać się środki unijne, których po pozyskaniu powinny być właściwe i efektywne spożytkowanie.

\section{References}

1. Borkowska S., Psychologiczne i organizacyjne aspekty zarządzania zasobami ludzkimi [ w] Rynek pracy i wykorzystanie potencjału pracy w Polsce; Książka jubileuszowa z okazji 80- lecia profesora Mieczysława Kabaja, Wyd. IPiSS, Warszawa 2014 (in. Pol.).

2. Broniatowska P., Majchrowska A., Żółkiweski Z., Wynagrodzenie minimalne w Polsce. Czy powinno być zróżnicowanie regionalne?,Studia BAS Nr.4 ( 36) Warszawa 2013 (in. Pol.).

3. Bukowski A., Magda G., Marć Ł., Zawistowski J., Źródła i perspektywy wzrostu produktywności w Polsce, Instytut Badań Strukturalnych, Departament Analiz i Prognoz Ministerstwa Gospodarki, Warszawa 2006 (in. Pol.).

4. Czepiel A., Kartus K., Cyrbus K., Jednakowa stawka płacy minimalnej hamuje rozwój polskich województw; Forum obywatelskie rozwoju, Analiza Forum nr.6/2013, Warszawa 2013 (in. Pol.).

5. Dobija M., Produktywność pracy a rozmiar sektora publicznego; Uniwersytet Ekonomiczny w Krakowie, Kraków s. 8 (in. Pol.).

6. Dudżińska - Głaz J., Zarządzanie kompetencjami pracowników jako jeden z elementów strategicznego zarządzania zasobami ludzkimi [w] Zarządzanie kapitałem intelektualnym w organizacji inteligentnej, (Red.) W. Harasim, Wyższa Szkoła Promocji, Warszawa 2012 (in. Pol.).

7. Jeruszka U., Czy i jakie korzyści odnoszą studenci z zatrudnienia [w] Rynek pracy i wykorzystanie potencjału pracy w Polsce; Wyd. IPiSS, Warszawa 2014 (in. Pol.).

8. Lewandowski A., Koloch G., Regulski A., Elastyczność rynków dóbr i pracy w Polsce na tle wybranych krajów europejskich, Instytut Badań Strukturalnych, Warszawa 2013 (in. Pol.).

9. Marciniak J., Zasady ustalania wynagrodzeń a dyskryminacja w zatrudnieniu, Wolters Kluwer, Warszawa 2014 (in. Pol.).

10. Opodatkowanie pracy $i$ wynagrodzenie minimalne. Wplyw na rynek pracy w Polsce, Departament Analiz i Prognoz, Ministerstwo Pracy i Polityki Społecznej, Warszawa 2013 (in. Pol.).

11. Raport: Kobiety i mężczyzn na rynku pracy, GUS, Warszawa 2014 (in. Pol.).

12. Raport: Sytuacja kobiet i mężczyzn na rynku pracy w 2013 roku, MPiPS, Warszawa 2014 (in. Pol.)

13. Sposoby świadczenia pracy w Polsce, PAIiIZ S.A., Warszawa 2013 (in. Pol.).

14. The Global Competitiveness Report 2014-2015, World Economic Forum, Lausanne 2014.

15. Wynagrodzenie minimalne w Polsce i w krajach Unii Europejskiej, Sedlak \& Sedlak, Warszawa 2014 (in. Pol.).

\section{ДЗЮРНИ Анна}

ад'юнкт,

факультет історичних та соціальних наук,

Університет кардинала Стефана Вишиньського у

Варшаві,

м. Варшава, Польща 


\section{ФАКТОРИ, ЩО ВИЗНАЧАЮТЬ РИНОК ПРАЦІ В ПРОЦЕСІ ФОРМУВАННЯ КОНКУРЕНТОСПРОМОЖНОСТІ КРАЇНИ}

Проблема. Сучасні проблеми ринкової економіки тісно пов'язані з ринком праці. Для економічної реальності кожної країни вони стають все більш актуальними. Все частіме наголошується, щчо ринок праці повинен бути продуктивним, гнучким і ефективним. Насправді, продуктивність $і$ гнучкість ринку прачі має ключове значення, з одного боку, для забезпечення прачівників гідною та добре оплачуваною роботою, з іншого - для знаходження шляху до найбільш ефективного використання роботодавиями людських ресурсів в економіці, отримуючи при цьому прибутки.

Метою наукової статті є виявлення факторів, які визначають ринок праиі в процесі формування конкурентоспроможності краӥни.

Результати. Здійснено аналіз конкурентоспроможності національної економіки з точки зору ефективності ринку праџі. Досліджено такі явища і процеси, як: співробітництво в галузі трудових відносин, гнучкість встановлення заробітної плати, практика найму $i$ звільнення, податкове навантаження на заробітну плату, вплив оподаткування на заохочення до прачі, тарифні ставки $i$ продуктивність прачі, рівень професійного менеджменту, здатність країни до утримання та залучення талантів, а також проблеми гендерної політики. Обгрунтовано суттеву різницю між рівнями конкурентоспроможності польської економіки та сусідніх країн. Аналіз та оцінка конкурентоспроможності Польщі крізь призму численних показників довели суттєве відхилення рівня конкурентоспроможності від задовільного. За значенням показника індексу глобальної конкурентоспроможності, що стосується навантаження на щотижневу заробітну плату, на першому місиі серед країн, що межують з Польщею, знаходиться Литва. Наступні місия посідають Росія, Польща, Словаччина, Чехія та Німеччина. Найгірші оцінки за изим показником в України.

Наукова новизна. Дістали подальшого розвитку дослідження впливу екзогенних та ендогенних факторів на функиіонування ринку праці в прочесі формування конкурентоспроможності краӥни. Зокрема, до важливих показників оцінки ефективності ринку праці, щџо впливає на конкурентоспроможність національної економіки, віднесено здатність країни утримувати таланти. На сучасному етапі людський капітал є найбільш важливим ресурсом національної економіки. Найважливішим багатством кожної країни є не стільки природні ресурси і валютні резерви, скільки ї̈ мешканці та їх знання, навички та компетениії. Людський капітал розглядається як дуже важливий фактор економічного розвитку крайни, особливо враховуючи людей з вищою освітою та людей талановитих. Обов'язком держави є забезпечення їх не лише роботою, а й умовами для подальшого розвитку.

Висновки. Ефективність ринку праиі $\epsilon$ важливою сферою оиінки стану та конкурентоспроможності економіки кожної країни. Ї̈ доцільно розглядати крізь призму багатьох змінних явищ і процесів, які повинні бути визначені, проаналізовані й оцінені. Доречним слід вважати підхід, відображений у рейтингах конкурентоспроможності, щз дозволяє оиінити не тільки характеристики ринку праці в певній країні, а й перевірити стан економічної ситуації в країні $i$ порівняти його з іншими крайнами. Характеристика ефективності ринку праці, як доводить ї̈ аналіз, є дуже складною проблемою. Важливими є всі фактори, що формують співробітництво в галузі трудових відносин, гнучкості встановлення заробітної плати, практики найму і звільнення, щотижневого навантаження на заробітну плату, впливу оподаткування на заохочення, тарифної ставки та продуктивності, опори на професійний менеджмент, здатності крайни утримувати таланти, здатності країни залучати таланти і питання статусу жінок на ринку праџі відносно чоловіків. Ïх виявлення та оцінка роблять можливими формування показників конкурентоспроможності, які характеризують ринок пращі. Рівень конкурентоспроможності польської економіки, яка очінюється з точки зору ефективності ринку прачі, слід розглядати як далекий від задовільного. Шанси на підвищення конкурентоспроможності слід вбачати в реальних діях, а не в деклараціях сочіально-економічної політики.

Ключові слова: ринок прачі, конкурентоспроможність, заробітна плата, податкова ставка, продуктивність праці, рівень занятості, еластичність. 